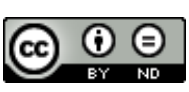

\title{
CURATESCAPE - TWORZENIE HISTORYCZNYCH REPREZENTACJI CYFROWYCH OPARTYCH NA LOKALIZACJI - OPROGRAMOWANIE DLA HUMANISTÓW I INSTYTUCJI DZIEDZICTWA
}

\section{Słowa kluczowe}

humanistyka cyfrowa; historia cyfrowa; historia mówiona; historia w przestrzeni publicznej; historia lokalna; kuratorstwo cyfrowe; archiwa cyfrowe; Curatescape; Omeka; cyfrowe dziedzictwo; dziedzictwo publiczne

\section{Keywords}

digital humanities; digital history; oral history; public history; local history; digital curation; digital archives; Curatescape; Omeka; digital heritage; public heritage

\section{Streszczenie}

Nowoczesne technologie informacyjno-komunikacyjne przyczyniły się do powstania humanistyki cyfrowej, w tym historii cyfrowej i „historiografii cyfrowej” oraz multime-

Dominik Mirosław Piotrowski. Doktor, pracuje w Bibliotece Uniwersyteckiej w Toruniu. W swej pracy odpowiedzialny jest między innymi za administrowanie systemami sieciowymi, optymalizację mediów społecznościowych oraz e-learning. Do zainteresowań badawczych autora należą open source'owe systemy zarządzania informacją, usługi biblioteczne funkcjonujące w modelu chmurowym, humanistyka cyfrowa oraz otwarta nauka. W wolnych chwilach zajmuje się grafiką komputerową i fotografią cyfrową, a także podróżuje oraz aktywnie działa w ramach społeczności skupionej wokół CMS Joomla! E-mail: Dominik.Piotrowski@bu.umk.pl

ORCID ID: 0000-0002-3372-4772 
dialnych i interaktywnych „historycznych reprezentacji cyfrowych”; z kolei rewolucja urządzeń i Internetu mobilnego wprowadziła nowe perspektywy w obszarze ustanawiania relacji oraz dzielenia się wiedzą i informacją. Jednocześnie coraz większego znaczenia nabiera potrzeba skutecznego zarządzania i sprawowania długoterminowej opieki nad treścią cyfrową oraz danymi w celach badawczych. Intencją artykułu jest wskazanie na potencjał, jaki oferuje otwartoźródłowe oprogramowanie Curatescape w kontekście tworzenia historycznych reprezentacji cyfrowych i „mobilnych projektów interpretacyjnych". Tekst bazuje na projekcie Cleveland Historical, który stanowi znakomity przykład połączenia humanistyki cyfrowej z historią w przestrzeni publicznej. Zamierzeniem artykułu jest również zasygnalizowanie możliwości, jakie humanistyka cyfrowa oferuje instytucjom dziedzictwa kulturalnego, organizacjom regionalnym oraz instytucjom dydaktycznym. W realizacji celu zastosowano metodę przeglądu literatury oraz studium przypadku. W artykule zaprezentowano także wyniki analizy dotyczącej architektury informacji oraz przeglądu funkcjonalności pakietu Curatescape, który stanowi zestaw wtyczek oraz motyw graficzny dla otwartego systemu Omeka. Tekst ukazuje potrzebę współpracy badaczy i pracowników instytucji dziedzictwa, członków lokalnych społeczności, nauczycieli oraz pasjonatów w celu stworzenia wysokiej jakości treści historycznych opartych na geolokalizacji. Badania wykazały, że projekty oparte na Curatescape mogą przyczynić się do wsparcia edukacji historycznej, budowania pamięci społecznej, aktywizacji publiczności, rozwoju turystyki kulturowej oraz realizacji kuratorstwa cyfrowego.

\section{Summary}

Curatescape - creating historical digital representations based on location software for humanists and heritage institutions

Modern information and communication technologies contributed to the emergence of digital humanities, including digital history and "digital historiography", as well as multimedia and interactive "historical digital representations". Moreover, the revolution of mobile Internet and devices introduced new perspectives in the area of establishing relationships and sharing knowledge and information. Simultaneously, the need of efficient management and long-term curation of digital content and data for research purposes becomes more and more significant. The intention of the article is to indicate the potential offered by the open-source software Curatescape in the context of creating historical digital representations and "mobile interpretation projects". The text bases on the Cleveland Historical project, which is a great example of merging digital humanities and public history. The article also aims at signalling possibilities offered by digital humanities to cultural heritage institutions, regional organisations, and educational institutions. This objective was acquired by implementing methods of literature review and case study. The article also presents output of analysis of information architecture and overview of function of the Curatescape suite, that is a set of plug-ins and a graphic theme for the open system Omeka. This text shows the need of cooperation between researchers and employees of heritage institutions, members of local communities, teachers, and hobbyists, in order to create high quality historical content based on geolocation. The research shows, that projects based on the Curatescape may contribute to supporting histor- 
ical education, creating social memory, activisation of the publicity, development of cultural tourism, and implementing digital curation.

\section{Wstęp}

Nowoczesne technologie informacyjno-komunikacyjne przyczyniły się do 1 powstania humanistyki cyfrowej, w tym historii cyfrowej i „historiografii cyfrowej"1. W centrum zainteresowania historiografii cyfrowej znajdują się multimedialne oraz interaktywne „historyczne reprezentacje cyfrowe” ${ }^{2}$, które oparte są na zdigitalizowanych oraz urodzonych cyfrowo (born digital) zasobach nauki i kultury. Jednocześnie gromadzeniem, przechowywaniem, opracowywaniem i udostępnianiem zasobów w formie cyfrowej zajmują się instytucje dziedzictwa, które odgrywają ważną rolę w projektach humanistyki cyfrowej oraz kreowaniu pamięci społecznej i tożsamości ${ }^{3}$. W związku z powyższym podstawowe zadania instytucji kultury rozszerzyły się o kuratorstwo cyfrowe ${ }^{4}$, gdyż coraz większego znaczenia nabiera sprawowanie długotrwałej opieki nad treścią cyfrową i danymi w celach badawczych. Z kolei pojawienie się sieci społecznościowych oraz rewolucja urządzeń i Internetu mobilnego wprowadziła nowe perspektywy w obszarze ustanawiania relacji oraz dzielenia się wiedzą i informacją. W rezultacie zmianom (przesunięciu) uległy również paradygmaty archiwalne, a ostatni paradygmat, oparty na archiwach społecznych, właśnie się rozwija i bazuje na współpracy archiwistów ze społecznościami oraz wykorzystaniu takich technologii jak Internet drugiej generacji czy media społecznościowe ${ }^{5}$.

Istotnym zagadnieniem z punktu widzenia analizowanej problematyki jest zastosowanie przez humanistów cyfrowych, archiwistów, bibliotekarzy i mu-

1 J. Sternfeld, Archival Theory and Digital Historiography: Selection, Search, and Metadata as Archival Processes for Assessing Historical Contextualization, „The American Archivist", nr 2 (2011), s. 544-575.

2 Tamże, s. 547.

3 Zob.: C. Brown, Memory, Identity and the Archival Paradigm: Introduction to the Special Issue, „Archival Science” 2013, nr 2-3, s. 85-93, https://link.springer.com/ article/10.1007\%2Fs10502-013-9203-z, (dostęp 24.11.2017).

4 A. Sabharwal, Digital Curation in the Digital Humanities: Preserving and Promoting Archival and Special Collections, Amsterdam [i pozostałe]: Elsevier/Chandos Publishing, 2015, s. 27.

5 T. Cook, Evidence, Memory, Identity, and Community: Four Shifting Archival Paradigms, „Archival Science” 2013, nr 2-3, s. 95-120, https://link.springer.com/article/10.1007/s10502-012-9180-7, (dostęp 24.11.2017). 
zealników aplikacji o otwartym dostępie do kodu źródłowego, służących do tworzenia kolekcji cyfrowych oraz prezentowania zawartości w postaci narracji cyfrowych. Interesującym rozwiązaniem w tym obszarze jest otwartoźródłowy system zarządzania treścią Omeka, stworzony w Roy Rosenzweig Center for History and New Media at George Mason University. Zawartość zgromadzona w systemie Omeka może być prezentowana, za pomocą zestawu rozszerzeń Curatescape, w postaci opartych na lokalizacji „opowieści” i „wycieczek”. Z uwagi na powszechną dostępność tej technologii, intencją artykułu jest wskazanie na potencjał, jaki oferuje otwarte oprogramowanie Curatescape w kontekście tworzenia mobilnych, zlokalizowanych geograficznie, historycznych reprezentacji cyfrowych. Tekst bazuje na projekcie Cleveland Historical, który stanowi znakomity przykład połączenia humanistyki cyfrowej z historią w przestrzeni publicznej. Zamierzeniem artykułu jest również zasygnalizowanie możliwości, jakie humanistyka cyfrowa oferuje instytucjom LAM (akronim ang. Libraries, Archives, Museums), instytucjom dydaktycznym, organizacjom i społecznościom regionalnym i lokalnym, oraz wolontariuszom i pasjonatom.

Na wstępie należy zaznaczyć, że zarówno w formie cyfrowej w sieci Internet, jak też w druku, dostępne są opracowania i różnego typu dokumenty, które są bardzo ważne z punktu widzenia niniejszego artykułu. W raporcie o charakterze białej księgi (ang. white paper) pt. Strategies for Mobile Interpretive projects for Humanists and Cultural Organizations ${ }^{6}$ Mark Tebeau charakteryzuje strategie tworzenia „mobilnych projektów interpretacyjnych” na przykładzie Cleveland Historical. Dokument stanowi cenne źródło informacji dotyczące projektu Cleveland Historical, w tym ewolucji i założeń mobilnego oprogramowania Curetescape, zastosowanych technologii, tworzenia narracji, a także nawiązywania współpracy podczas rozwoju projektu z nauczycielami, naukowcami, studentami, członkami lokalnej społeczności oraz instytucjami kultury. Kolejnym interesującym źródłem informacji jest referat pt. From Exhibition to Conversation: The Elusive Art of Digital Storytelling, autorstwa Marka Southera, który wygłoszony został w 2016 r. podczas Network Detroit Conference ${ }^{7}$. Souther skupia się na ewolucji projektu Cleveland Historical w kontekście organizowania miasta

${ }^{6}$ M. Tebeau, White Paper: Strategies for Mobile Interpretive projects for Humanists and Cultural Organizations, „National Endowment for the Humanities”, 2013, http:// mobilehistorical.curatescape.org/, (dostęp 24.11.2017).

7 M.J. Souther, From Exhibition to Conversation: The Elusive Art of Digital Storytelling, Detroit, MI 2016, http://digitalcommons.wayne.edu/cgi/viewcontent.cgi?artic$l e=1001 \&$ context $=$ networkdetroit, $($ dostęp 24.11.2017) 
i sprawowania nad nim opieki poprzez wzbogacanie wiedzy o historii lokalnej oraz współpracy z otoczeniem. Innym ciekawym opracowaniem jest biała księga pt. Adapting Mobile Humanities Interpretation in East Africa ${ }^{8}$. Autorami wspomnianego tekstu jest Mark J. Souther, Meshack Owino oraz Erin Bell, którzy na przykładzie projektu Curating Kisumu ${ }^{9}$ omawiają dostosowanie platformy Curatescape na potrzeby Afryki Wschodniej ${ }^{10}$. Z kolei w aspekcie kuratorstwa cyfrowego, humanistyki cyfrowej i historii cyfrowej oraz nowoczesnej roli kuratora cyfrowego na uwagę zasługuje książka autorstwa Arjuna Sabharwala, pt. Digital Curation in the Digital Humanities: Preserving and Promoting Archival and Special Collections ${ }^{11}$. Innym ważnym źródłem informacji w tym zakresie jest specjalistyczny serwis prowadzony przez The Digital Curation Centre ${ }^{12}$, a także dwa polskojęzyczne artykuły, które ukazały się na łamach Biuletynu EBIB, mianowicie Trwała ochrona zasobów cyfrowych - podstawowe pojęcia ${ }^{13}$ autorstwa Anety Januszko-Szakiel i in. oraz Kurator danych cyfrowych - nowe stanowisko $w$ bibliotece naukowej ${ }^{14}$ autorstwa Renaty Patela, Anny Piwko-Łętek i Oliwiera Sadlika. Na polu historii w przestrzeni publicznej interesujący wydaje się artykuł Joanny Wojdon pt. Public history, czyli historia $w$ przestrzeni publicznej ${ }^{15}$, a z perspektywy uprawiania historii w środowisku cyfrowym na uwagę zasługuje publikacja Marcina Wilkowskiego pt. Wprowadzenie do historii cyfrowe ${ }^{16}$. Natomiast w kontekście historiografii cyfrowej oraz historycznych reprezentacji cyfrowych nie sposób nie wspomnieć o artykule Joshuy Sternfelda

${ }^{8}$ M.J. Souther, M. Owino, E.J. Bell, Adapting Mobile Humanities Interpretation in East Africa, „National Endowment for the Humanities”, 2016, http://csudigitalhumanities. org/wp-content/uploads/2016/03/HD-51912-14_White-Paper.pdf, (dostęp 24.11.2017).

9 MaCleKi | Curating Kisumu, http://macleki.org/, (dostęp 24.11.2017).

10 M.J. Souther, M. Owino, E.J. Bell, Adapting Mobile Humanities, s. 2.

11 A. Sabharwal, Digital Curation in the Digital Humanities.

12 Digital Curation Centre, http://www.dcc.ac.uk/, (dostęp 24.11.2017).

13 A. Januszko-Szakiel, Trwała ochrona zasobów cyfrowych - podstawowe pojęcia, „Biuletyn EBIB” 9 (154), s. 1-12, 2015, http://open.ebib.pl/ojs/index.php/ebib/article/ view/311, (dostęp 24.11.2017).

${ }^{14}$ R. Patela, A. Piwko-Łętek, O. Sadlik, Kurator danych cyfrowych - nowe stanowisko w bibliotece naukowej, „Biuletyn EBIB” 9 (154), s. 1-12, 2015, http://open.ebib.pl/ojs/ index.php/ebib/article/view/307, (dostęp 24.11.2017).

15 J. Wojdon, Public history, czyli historia w przestrzeni publicznej, „Klio - Czasopismo Poświęcone Dziejom Polski i Powszechnym” 3/34, 2015, s. 30, http://apcz.umk.pl/ czasopisma/index.php/KLIO/article/view/KLIO.2015.027/7711, (dostęp 24.11.2017).

${ }^{16}$ M. Wilkowski, Wprowadzenie do historii cyfrowej, Gdańsk 2013, https://depot. ceon.pl//handle/123456789/2001 (dostęp 24.11.2017). 
pt. Archival Theory and Digital Historiography: Selection, Search, and Metadata as Archival Processes for Assessing Historical Contextualization ${ }^{17}$.

Na potrzeby niniejszego artykułu należałoby wprowadzić kilka istotnych definicji związanych z rozpatrywanym obszarem tematycznym. Trzeba jednak zaznaczyć, że w literaturze przeważnie funkcjonuje wiele różnych określeń przywoływanych pojęć. Dlatego też, dokonany wybór opierał się na subiektywnej ocenie użyteczności danej definicji w kontekście omawianej problematyki.

- Historia cyfrowa (ang. digital history) to według cytowanej przez Marcina Wilkowskiego definicji stworzonej przez The Roy Rosenzweig Center for History and New Media „podejście do badania i reprezentowania przeszłości uwzględniające nowe technologie komunikacyjne, takie jak komputery i Sieć. Opiera się na istotnych właściwościach cyfrowej rzeczywistości, takich jak bazy danych, hipertekstualizacja i sieci, aby tworzyć i udostępniać wiedzę historyczną"18.

- Historia mówiona (ang. oral history) to „dziedzina nauki oraz metoda gromadzenia, zachowywania i interpretowania głosów i wspomnień ludzi, społeczności oraz uczestników przeszłych wydarzeń"19.

- Historia w przestrzeni publicznej (ang. public history) 'w swej naturze kładzie nacisk na ludzi, na odbiorców i publiczność' ${ }^{20}$. Polem zainteresowań badawczych historii w przestrzeni publicznej jest „historia regionalna oraz lokalna" ${ }^{21}$. Historia ta uprawiana jest także poza tradycyjnymi instytucjami naukowymi ${ }^{22}$.

- Historiografia cyfrowa (ang. digital historiography) stanowi „interdyscyplinarne badanie interakcji technologii cyfrowej z praktyką historyczną"23. Obszarem zainteresowań historiografii cyfrowej są historyczne reprezentacje cyfrowe (ang. digital historical representations), czyli „cyfrowe archiwa, kolekcje, bazy danych, strony Internetowe, narzędzia pedagogiczne, aplikacje mobilne i wizualizacje geoprzestrzenne"24, za-

17 J. Sternfeld, Archival Theory and Digital Historiography.

${ }_{18}$ M. Wilkowski, Wprowadzenie do historii cyfrowej, s. 9.

19 Oral History: Defined, http://www.oralhistory.org/about/do-oral-history/, (dostęp 24.11.2017).

20 J. Wojdon, Public history, czyli historia w przestrzeni publicznej, s. 30-34.

21 Tamże, s. 34.

${ }^{22}$ M. Wilkowski, Historia publiczna, „Tygodnik Powszechny” (dodatek: Anamneses: '89 - korzenie wolności) (47), 2013, https://www.tygodnikpowszechny.pl/historia-publiczna-21168, (dostęp 24.11.2017).

23 J. Sternfeld, Archival Theory and Digital Historiography, s. 550.

24 Tamże, s. 547. 
wierające różnego typu treści, informacje i dane, które umożliwiają reprezentację miejsc, osób, wydarzeń i przedmiotów, które należą już do historiii ${ }^{25}$.

- Humanistyka cyfrowa (ang. digital humanities) jest to „Humanistyka w dialogu z technologiami cyfrowymi" ${ }^{26}$.

- Interpretacja humanistyczna, to - w nawiązaniu do tezy Jerzego Kmity, „rodzaj wyjaśniania“27. Interpretacja humanistyczna stanowi „odkrywanie sensu i wartości ludzkich dzieł"28,

- Kuratorstwo cyfrowe (ang. digital curation) „obejmuje utrzymywanie, ochronę i dodawanie wartości cyfrowym danym badawczym w całym cyklu ich życia" 29 .

- Opowieści cyfrowe bądź opowiadania cyfrowe (ang. digital storytelling) to „praktyka używania narzędzi komputerowych do opowiadania historii” ${ }^{30}$.

- Otwarte oprogramowanie (ang. open source) jest to oprogramowanie, którego „kod źródłowy udostępniony [jest] publicznie”31.

\section{Materiały i metody}

Przedmiotem niniejszych badań jest możliwość tworzenia historycznych reprezentacji cyfrowych oraz edukacyjnych mobilnych projektów interpretacyjnych opartych na oprogramowaniu typu open source. W realizacji celu zastosowano metodę przeglądu literatury. Zasięg wydawniczo-formalny objął wydawnictwa

25 A. Sabharwal, Digital Curation in the Digital Humanities, s. 56-57.

${ }^{26}$ Tamże, s. 29, cyt. za: D.J. Cohen, F. Frabetti, D. Buzzetti, J.D. Rodriguez-Velasco, Defining the Digital Humanities, „Columbia University Academic Commons”, 2011, https://academiccommons.columbia.edu/catalog/ac\%3A150603, (dostęp 24.11.2017).

${ }_{27}$ M. Bonecki, Jerzy Kmita - interpretacja humanistyczna i społeczno-regulacyjna koncepcja kultury, [w]: Filozofia Publiczna i Edukacja Demokratyczna, 1 (2), 2012, s. 187-188, http://cejsh.icm.edu.pl/cejsh/element/bwmeta1.element.desklight-af7ce386-852a-48e3-8851-d322af60ee7f, (dostęp 24.11.2017).

${ }^{28}$ Materiaty do nauk administracyjnych/Interpretacja humanistyczna, Wikibooks, biblioteka wolnych podręczników (2017), https://pl.wikibooks.org/wiki/Materia\%C5\%82y_ do_nauk_administracyjnych/Interpretacja_humanistyczna, (dostęp 24.11.2017).

${ }^{29}$ What is digital curation? | Digital Curation Centre, http://www.dcc.ac.uk/digitalcuration/what-digital-curation, (dostęp 24.11.2017).

30 What is Digital Storytelling?, http://digitalstorytelling.coe.uh.edu/page. cfm?id=27\&cid=27, (dostęp 24.11.2017).

31 J. Illg, T. Illg, Słownik informatyczny, angielsko-polski, polsko-angielski, Videograf II, Katowice 2003, s. 173. 
zwarte, artykuły z czasopism elektronicznych oraz strony Internetowe poświęcone omawianemu zagadnieniu, zaś chronologiczny - lata 2000-2017. Jednocześnie badaniom poddano studium przypadku skupiające się na projekcie Cleveland Historical. Przeprowadzono także analizę dotyczącą architektury informacji oraz przeglądu funkcji pakietu Curatescape (opartą na testowo zainstalowanym oprogramowaniu). Tekst ukazuje potrzebę współpracy między różnymi podmiotami w celu stworzenia wysokiej jakości treści historycznych. Badania przeprowadzone zostały w okresie od września do grudnia 2017 r.

Postawiono następujące pytania badawcze: czym charakteryzuje się mobilny projekt interpretacyjny Cleveland Historical? Jak zaprojektowana została architektura informacji oraz jakie funkcjonalności posiada otwarta wersja oprogramowania Omeka + Curatescape? Jakie możliwości humanistyka cyfrowa oferuje instytucjom kultury, instytucjom edukacyjnym oraz lokalnym społecznościom?

\section{Rezultaty}

\section{Cleveland Historical, czyli mobilny projekt interpretacyjny}

Interesującym przykładem współpracy świata nauki z instytucjami dziedzictwa kulturalnego oraz społecznością jest mobilny projekt interpretacyjny Cleveland Historical (dalej CH). CH opracowany został w The Center for Public History + Digital Humanities (dalej CPHDH), które założone zostało przez Marka Tebeau oraz Marka J. Southera w 2008 r. w Cleveland State University. CPHDH „dąży do rozwoju historii w przestrzeni publicznej we wszystkich jej wymiarach"32, a w realizacji swojej misji stosuje i popularyzuje nowoczesne technologie oraz podejście oparte na humanistyce cyfrowej ${ }^{33}$. Głównymi projektami cyfrowymi, które powstały w ramach $\mathrm{CPHDH}$ są:

- Cleveland Historical - mobilna aplikacja dostępna na mobilne systemy iOS i Android, oparta na komercyjnej wersji Curatescape i jednocześnie otwartoźródłowej wersji Curatescape dostępnej przez interfejs WWW,

- Curatescape - wersja open source oraz natywna aplikacja komercyjna umożliwiająca publikowanie treści opartych na lokalizacji,

${ }^{32}$ Mission | Center for Public History + Digital Humanities at Cleveland State University, https://csudigitalhumanities.org/about/mission/, (dostęp 24.11.2017).

33 Tamże. 
- Cleveland Voices - platforma mająca na celu gromadzenie wywiadów historii mówionej dokumentujących rozwój miasta Cleveland w stanie Ohio $^{34}$.

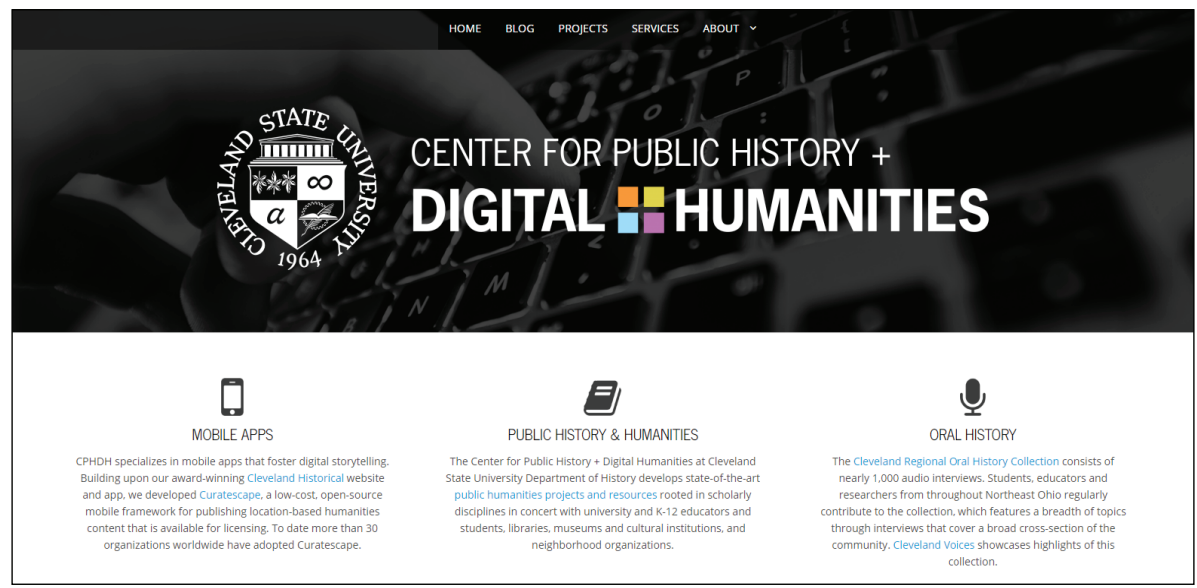

II. 1. Center for Public History + Digital Humanities at Cleveland State University Źródło: Center for Public History + Digital Humanities at Cleveland State University, https://csudigitalhumanities.org, (dostęp 24.11.2017)

W aspekcie Cleveland Historical należy powiedzieć, że stanowi on wspólny mianownik wcześniejszych projektów realizowanych przez twórców $\mathrm{CPHDH}$ w obszarze historii miejskiej i historii w przestrzeni publicznej35. Należy do nich opublikowana w 2006 r. witryna Cleveland Cultural Gardens ${ }^{36}$, sprawująca opiekę cyfrową nad publicznymi ogrodami (oraz znajdującymi się w nich rzeźbami) miasta Cleveland, które upamiętniają różne grupy narodowe i etniczne ${ }^{37}$ na tle dwudziestowiecznej historii Stanów Zjednoczonych ${ }^{38}$.

${ }^{34}$ Cleveland Voices, https://clevelandvoices.org/, (dostęp 24.11.2017).

${ }^{35}$ M. Tebeau, Update: Cleveland Historical to Curatescape, http://csudigitalhumanities. org/2011/07/update-cleveland-historical/, (dostęp 24.11.2017).

${ }^{36}$ Cleveland Cultural Gardens, http://www.culturalgardens.org/, (dostęp 24.11.2017).

37 Wśród ogrodów znajduje się również Ogród polski wraz z popiersiami sławnych naukowców, artystów i pisarzy takich jak Mikołaj Kopernik, Fryderyk Chopin i Henryk Sienkiewicz. Zob.: Polish Garden \& Cleveland Cultural Gardens, http://www.culturalgardens.org/garden/polish-garden/, (dostęp 24.11.2017).

38 Cleveland Cultural Gardens | Center for Public History + Digital Humanities at Cleveland State University, https://csudigitalhumanities.org/2008/01/cleveland-culturalgardens/, (dostęp 24.11.2017). 


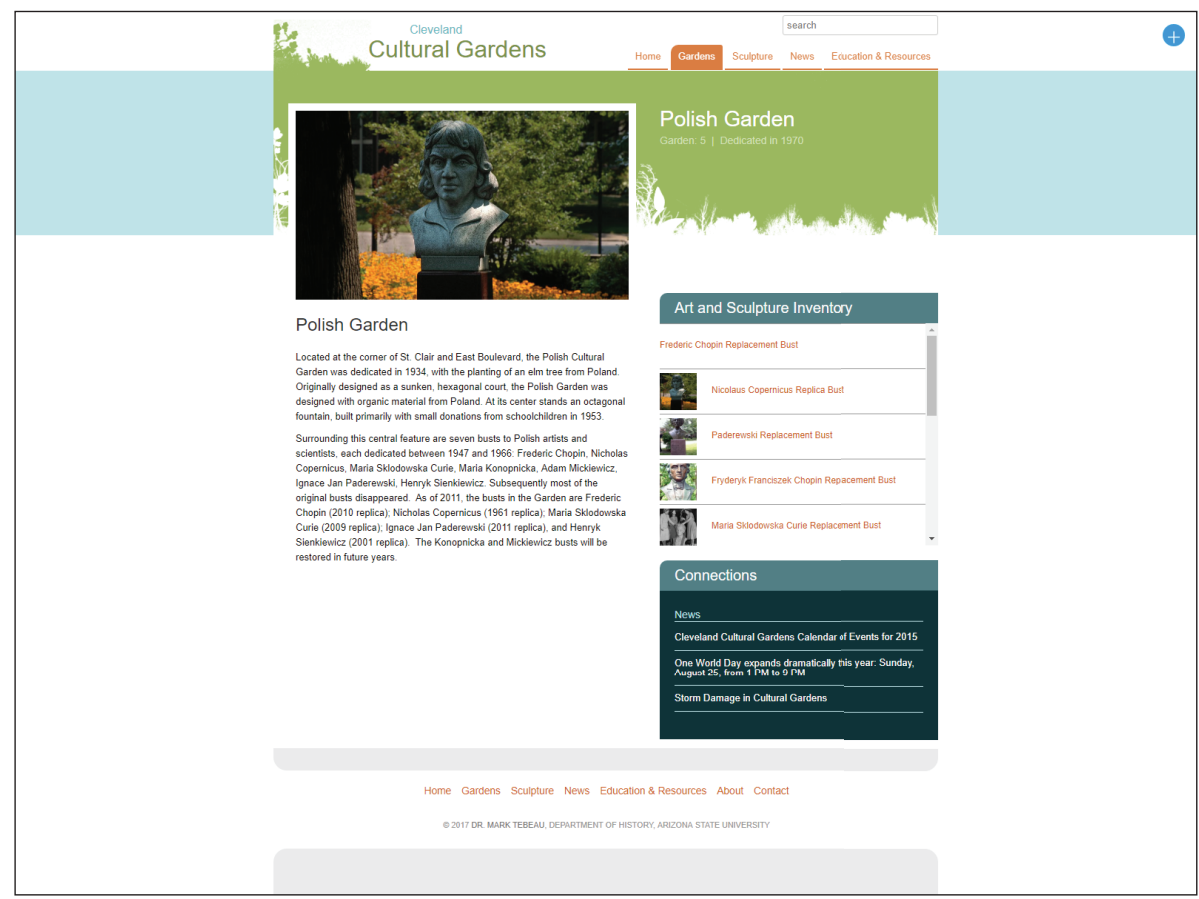

II. 2. Polish Garden w witrynie Cleveland Cultural Gardens

Źródło: Polish Garden, http://www.culturalgardens.org/garden/Polish-Garden/ (dostęp 24.11.2017)

Kolejnym ważnym projektem był oddany w 2008 r. Euclid Corridor Oral History Project, który „eksploruje historię i tożsamość regionu przez pryzmat Euclid Avenue w Cleveland"39, czyli głównej arterii Cleveland. W ramach projektu, za pomocą metody historii mówionej, wygenerowanych zostało wiele źródeł historycznych, które w połączeniu z archiwalnymi fotografiami oraz tekstami interpretacyjnymi prezentowane były $\mathrm{w}$ formie wystaw cyfrowych. Były to „multimedialne portrety znanych lub zapomnianych miejsc”40, które wyświetlane były w rozmieszczonych wzdłuż Euclid Avenue interaktywnych kioskach, znajdujących się na przystankach autobusowych ${ }^{41}$, a także udostępnione

${ }^{39}$ Euclid Corridor Transportation Project, http://academic.csuohio.edu/euclidcorridor/, (dostęp 24.11.2017).

${ }^{40}$ M.J. Souther, From Exhibition to Conversation.

${ }^{41}$ Center for Public History + Digital Humanities, Euclid Corridor Oral History Pro- 
$\mathrm{w}$ trybie online $\mathrm{H}^{42}$. Wystawy miały na celu pomoc przy ponownym zobrazowaniu miasta. Projekt co prawda nie spełnił pokładanych w nim oczekiwań, ale za to pozostała „idea organizowania miasta jako narzędzia do nauczania i sposobu przekształcania opinii publicznej o miejscach"43.

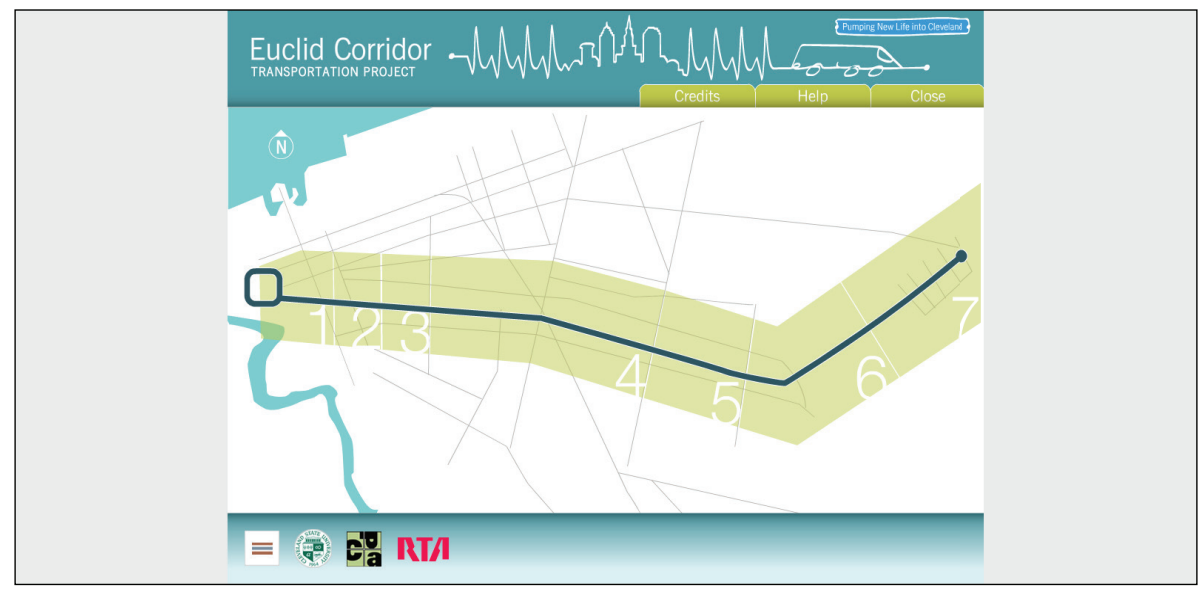

II. 3. Euclid Corridor Transportation Project

Źródło: Euclid Corridor Transportation Project, http://academic.csuohio.edu/euclidcorridor/ (dostęp 24.11.2017)

Szybki rozwój urządzeń i Internetu mobilnego sprawił, że inicjatywa organizowania (kuratorstwa) miasta poprzez cyfrowe wystawy oraz zbudowania wokół projektu publiczności wchodzącej w interakcje z treścią, przeniesiona została do mobilnego projektu Cleveland Historical ${ }^{44}$. Podobnie jak w poprzedniej inicjatywie, integracja różnych typów treści pozwalała na stworzenie interpretacyjnych „portretów miejsc” w obszarze miasta. W roku 2011 r. swoją premierę miała mobilna aplikacja na popularne systemy iOS oraz Android ${ }^{45}$. W latach 2011-2012 uzyskano grant z Cleveland State University Faculty Research Development, a później wsparcie finansowe z National Endowment for

ject, https://csudigitalhumanities.org/2008/05/euclid-corridor-oral-history-project-2/, (dostęp 24.11.2017).

${ }^{42}$ Euclid Corridor Transportation Project.

${ }_{43}$ M.J. Souther, From Exhibition to Conversation, s. 2.

44 Tamże, s. 3.

45 Tamże. 
the Humanities ${ }^{46}$, dzięki czemu powstał start-up w celu budowy aplikacji open source Mobile Historical (oraz analizy możliwości rozszerzenia rozwiązania poza Cleveland ${ }^{47}$ ). Po pewnym czasie zmieniono nazwę Mobile Historical na Curatescape, którą w 2014 r. przebudowano, dodając nowoczesne rozwiązania oparte na open source $e^{48}$.

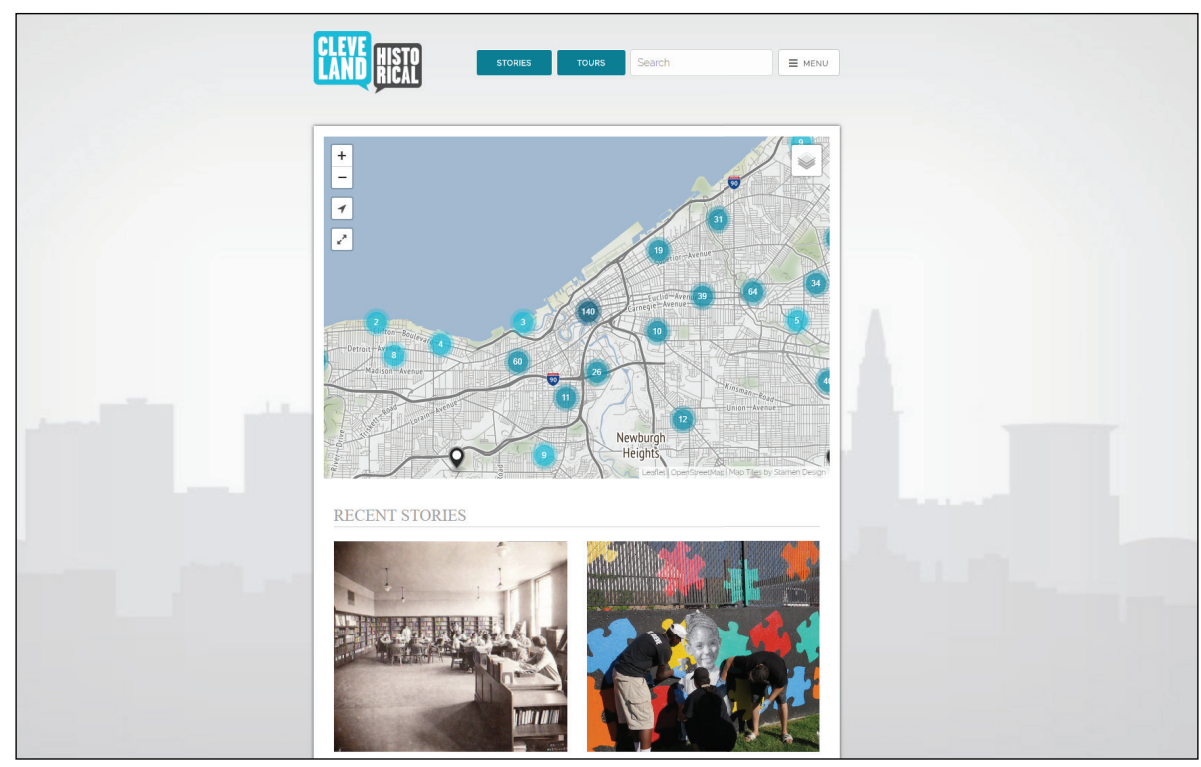

II. 4. Strona startowa Cleveland Historical

Źródło: Cleveland Historical, https://clevelandhistorical.org/ (dostęp 24.11.2017)

Jak zaznacza Mark Tebeau: „głównym założeniem intelektualnym stojącym za naszą pracą jest przekonanie, że miasta, krajobrazy i sama historia mogą być nadzorowane przy współpracy różnorodnych wspólnot i w różnych formach medialnych" ${ }^{49}$. Autorzy CH postrzegają miasto jako „żywe muzeum”, które składa się z wielu warstw narracji o miejscach ${ }^{50}$, umożliwiając interpretowanie i „uporządkowanie miasta” poprzez badaczy zajmujących się historią w prze-

${ }^{46}$ NEH grant details. Mobile Historical, https://securegrants.neh.gov/publicquery/ main.aspx?f=1\&gn=HD-51456-11, (dostęp 24.11.2017).

47 M. Tebeau, Update: Cleveland Historia.

${ }_{48}$ M.J. Souther, From Exhibition to Conversation, s. 3-4.

49 M. Tebeau, Update: Cleveland Historia.

50 Por. M. Tebeau, Curatescape Workshop - YouTube - Brown University, 2015, https:// 
strzeni publicznej ${ }^{51}$. Warstwy stanowią interpretacyjne opowieści, lokalizacje geograficzne, archiwalne filmy, ilustracje, wywiady historii mówionej, tagi ${ }^{52}$ oraz wycieczki ${ }^{53}$. Cechą szczególną mobilnego projektu interpretacyjnego jest zatem interpretacja humanistyczna, która objawia się w położeniu akcentu „na opowiadanie historii poprzez starannie skonstruowane warstwy tekstu i cyfrowych artefaktów multimedialnych"54.

Tebeau uważa, że „słuchanie, a nie tylko czytanie tekstu lub przeglądanie fotografii może wywoływać emocjonalne wrażenia miejsca"55. W związku z powyższym Tebeau „podkreśla percepcję słuchową̨ ${ }^{56}$ [ang. aurality] jako kluczowy element w cyfrowych, a zwłaszcza mobilnych, projektach interpretacyjnych" ${ }^{57}$. Dlatego też opowieści cyfrowe utworzone zostały dzięki integracji wysokiej jakości tekstów interpretacyjnych, archiwalnych zdjęć i filmów, nagrań historii mówionej, a także specjalnie przygotowanych, „osadzonych” opowiadań cyfrowych w formie stylizowanych pokazów archiwalnych zdjęć opatrzonych komentarzem głosowym. Wskutek tego powstały materiały edukacyjne do nauki historii $\mathrm{w}$ formie opowieści cyfrowych, a zarazem unikatowe eksponaty cyfrowego dziedzictwa kulturalnego. Należy zaznaczyć, że w głównej mierze autorami opowieści znajdujących się w CH są zarówno studenci oraz badacze, jak również uczniowie szkół podstawowych i średnich ${ }^{58}$.

W celu dotarcia do ludzi oraz zaangażowania się publiczności w upowszechnianie zawartości i dzielenie się informacjami zorganizowano różnego typu wydarzenia, wycieczki i spotkania, przeprowadzono akcje promocyjne oraz wykorzystano media społecznościowe. Należy zaznaczyć, że w przypadku $\mathrm{CH}$ ludzie dzielą się również materiałami archiwalnymi dotyczącymi historii lokalnej, co z kolei przekłada się na nowe badania i odkrywanie kolejnych historii zwią-

www.youtube.com/watch?v=SgX_3_iT3yQ, (dostęp 24.11.2017).; M. J. Souther, M. Owino, E.J. Bell, Adapting Mobile Humanities Interpretation, s. 1.

${ }^{51}$ M. Tebeau, White Paper: Strategies for Mobile.

52 M.J. Souther, M. Owino, E.J. Bell, dz. cyt., s. 1.

${ }^{53}$ M. Tebeau, Curatescape Workshop.

54 Tenże, White Paper: Strategies for Mobile.

55 Tenże, Case Study: "Visualizing Oral History". Oral history in the digital age, red. D. Boyd, S. Cohen, B. Rakerd, D. Rehberger, Washington, D.C. 2012, http://ohda.matrix. msu.edu/2012/06/visualizing-oral-history/, (dostęp 24.11.2017).

56 Przyp. tłum.

${ }^{57}$ M. Tebeau, Listening to the City. Oral History and Place in the Digital Era, "The Oral History Review", 2013, 40 (1), s. 25-35.

58 Por.: Tenże, White Paper: Strategies for Mobile.; tenże, Update: Cleveland Historical. 
zanych z miejscami ${ }^{59}$. Na potrzeby $\mathrm{CH}$ wiele cennych informacji pozyskuje się także dzięki integracji z Disqus, który umożliwia czytelnikom dzielenie się wiedzą w komentarzach ${ }^{60}$.

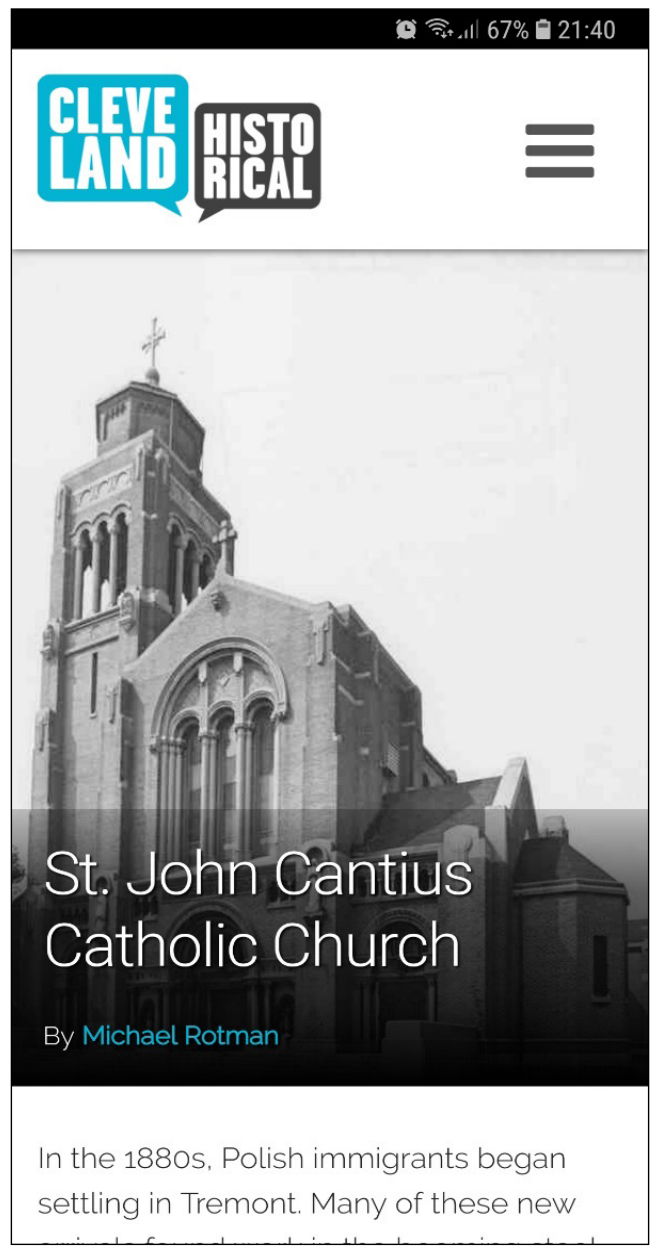

II. 5. Mobilny widok wprowadzenia do opowieści o założonym przez Polaków kościele St. John Cantius Catholic Church Źródło: M. Rotman, St. John Cantius Catholic Church, http://clevelandhistorical.org/items/show/101 (dostęp 24.11.2017)

59 M.J. Souther, From Exhibition to Conversation, s. 6.

60 Tamże. 
CH stał się popularny i zaczął szeroko oddziaływać61. Już w 2001 r. w CH znajdowało się 200 opowieści, 1500 zdjęć, 500 plików audio oraz 100 filmów62. Obecnie „Cleveland Historical stał się zaufanym źródłem historii lokalnej”63 posiadając 619 opowieści oraz 31 wycieczek (stan na dzień 12.11.2017). Uznaniem cieszy się również oprogramowanie Curatescape, czego dowodem jest lista 48 projektów zarejestrowanych na stronie domowej aplikacji, a są to między innymi Explore Baltimore Heritage, Spokane Historical, New Orleans Historical czy Discover Indiana ${ }^{64}$. Dwie wybrane inicjatywy z zakresu historii w przestrzeni publicznej, które bazują na tytułowym oprogramowaniu oraz wykorzystują zasoby archiwów i bibliotek, zaprezentowane zostały w dalszej części niniejszego artykułu.

\section{Curatescape - rozszerzenie dla Omeka}

Skupiając się na Curatescape, należy zaznaczyć, że w białej księdze pt. Adapting Mobile Humanities Interpretation in East Africa znajduje się następująca charakterystyka analizowanego oprogramowania: „Curatescape oferuje niedrogi i łatwy w użyciu zestaw narzędzi, który umożliwia małym i średnim organizacjom lub uczelniom tworzenie bogatych, rezonujących projektów z zakresu humanistyki publicznej, które zapraszają społeczeństwo do dialogu na temat związków między przeszłością i teraźniejszością, które osadzone są w krajobrazie" $^{\prime 65}$. Curatescape posiada szeroki zakres zastosowań, ponieważ jest to aplikacja „do interpretacji historii, kultury i środowiska na urządzeniach mobilnych”66.

Curatescape w wersji open source stanowi szkielet bazowy (framework), dzięki któremu istnieje możliwość stworzenia mobilnych witryn internetowych oraz natywnych aplikacji mobilnych służących do publikowania treści humanistycznych opartych na geolokalizacji ${ }^{67}$. Wersja Curatescape do tworzenia mobilnych witryn stanowi otwartoźródłowy zestaw obligatoryjnych i opcjonalnych

${ }^{61}$ M. Tebeau, Curatescape Workshop.

62 Tenże, Update: Cleveland Historical.

${ }^{63}$ M. J. Souther, From Exhibition to Conversation, s. 8.

${ }^{64}$ Projects | Curatescape, https://curatescape.org/projects/, (dostęp 24.11.2017).

65 M.J. Souther, M. Owino, E.J. Bell, dz. cyt., s. 2.

${ }^{66}$ M. Tebeau, Update: Cleveland Historical.

${ }^{67}$ Curatescape | A web and mobile app framework for curating the landscape, https:// curatescape.org/, (dostęp 24.11.2017). 
wtyczek oraz responsywny motyw graficzny do systemu Omeka ${ }^{68}$. Komponenty te dostępne są w repozytorium kodu w serwisie GitHub. Z kolei natywne aplikacje mobilne stanowią ofertę komercyjną opartą na odpłatnych licencjach. Twórcy oprogramowania zastrzegają jednak, że dochody z oferty komercyjnej przeznaczone są na rozwój otwartego kodu Curatescape ${ }^{69}$. Rozwiązanie, zarówno w wersji otwartej, jak i komercyjnej, wykorzystuje oprogramowanie Omeka jako system do zarządzania treścią i metadanymi.

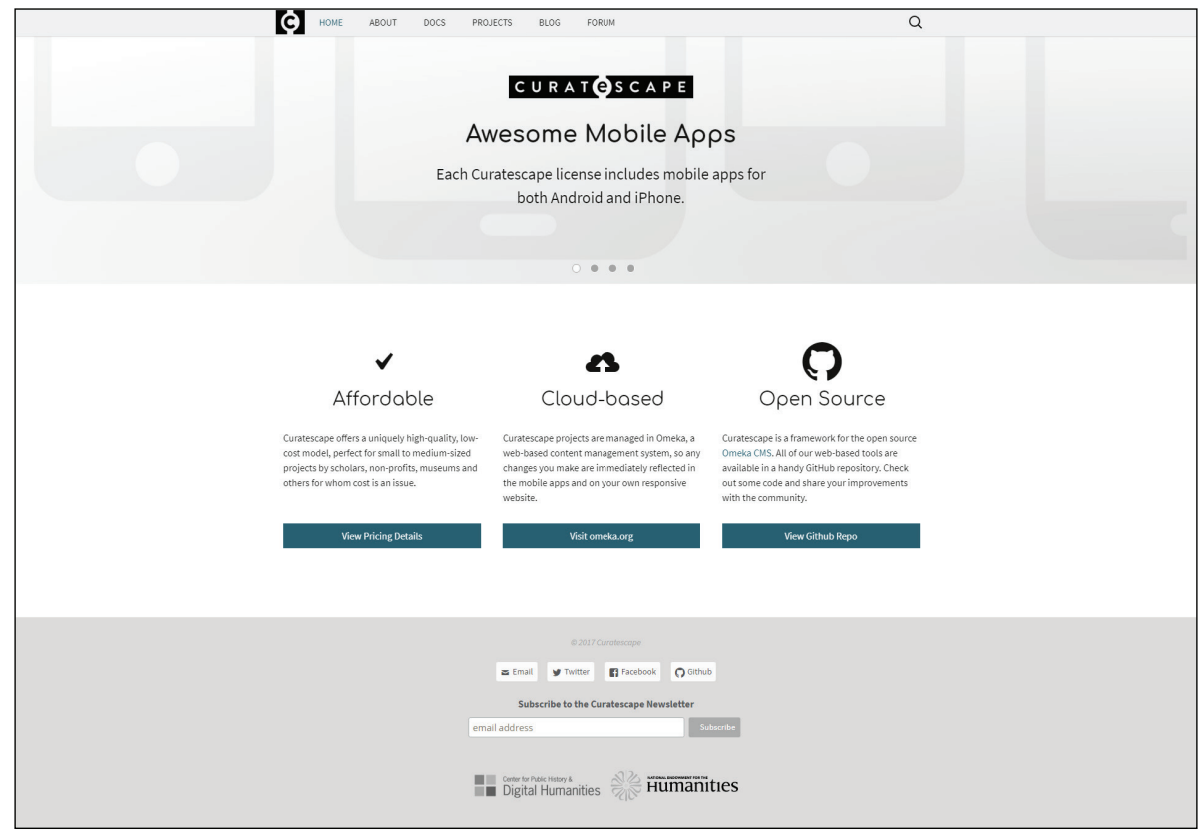

II. 6. Curatescape | A web and mobile app framework for curating the landscape Źródło: Curatescape, https://curatescape.org (dostęp 24.11.2018)

Curatescape (open source) posiada dokumentację w formie wiki w serwisie GitHub $^{70}$, a także przeznaczony mu kanał komunikacyjny bazujący na forum ${ }^{71}$.

${ }^{68}$ Omeka, http://omeka.org/, (dostęp 24.11.2017).

${ }^{69}$ Pricing | Curatescape, https://curatescape.org/about/pricing/, (dostęp 24.11.2017).

${ }^{70}$ Home - CPHDH/Curatescape Wiki • GitHub, https://github.com/CPHDH/Curatescape/wiki, (dostęp 24.11.2017).

${ }^{71}$ Curatescape Forum, http://forum.curatescape.org/, (dostęp 24.11.2017). 
Aplikacja w wersji otwartej może być posadowiona na platformie serwerowej zgodnej z architekturą LAMP (Linux, Apache, MySQL, PHP) ${ }^{72}$. Warto również zaznaczyć, że istnieją dwa sposoby instalacji Curatescape ${ }^{73}$ :

1. Instalacja Omeka, a następnie doinstalowanie wtyczek i motywu graficznego,

2. Instalacja pakietu zawierającego wszystkie niezbędne części składowe ${ }^{74}$ (podejście wybrane na potrzeby niniejszych badań).

Po udanym procesie instalacji należy zalogować się do systemu, przejść na stronę z ustawieniami i uzupełnić informacje o witrynie, a następnie aktywować dedykowany motyw graficzny oraz wtyczki. Dodatkowe rozszerzenia umożliwiają m.in. generowanie danych $\mathrm{w}$ formacie JSON, dodawanie niestandardowych funkcjonalności, określanie położenia geograficznego, tworzenie stron statycznych bądź definiowanie słownika kontrolowanego.

W przeciwieństwie do tradycyjnych otwartych aplikacji do tworzenia archiwów cyfrowych (np. DSpace lub Fedora) gromadzących „wyjęte z kontekstu” pojedyncze obiekty cyfrowe, architektura informacji Curatescape zaprojektowana została w celu opowiadania historii o różnych miejscach (publikowania treści humanistycznych opartych na lokalizacji ${ }^{75}$ ), za pomocą metody storytelling ${ }^{76}$. Oprogramowanie posiada możliwość integracji różnych typów treści oraz ich katalogowania za pomocą ustrukturyzowanych metadanych w standardzie Dublin Core $^{77}$. Od strony zaplecza (backend) systemu Omeka + Curatescape znajduje się interfejs redaktora (administratora), w którym opowieści reprezentowane są za pomocą pojedynczych elementów (items). Elementy składają się z tekstu, różnych plików (np. archiwalnych ilustracji, nagrań audio i video wraz z towarzyszącymi im metadanymi), tagów oraz geolokalizacji. Z architekturą tą związany jest przepływ pracy (ang. workflow) podczas tworzenia nowego elementu (opowieści). Na początek w trybie edycji elementu należy podać

${ }^{72}$ Wraz z zainstalowanym oprogramowaniem ImageMagick do obsługi ilustracji.

${ }^{73} \mathrm{GitHub}-\mathrm{CPHDH} / \mathrm{Curatescape:} \mathrm{A} \mathrm{set} \mathrm{of} \mathrm{add-ons} \mathrm{for} \mathrm{the} \mathrm{Omeka} \mathrm{content} \mathrm{management}$ system, designed specifically for location-based narrative content, and compatible with paid Curatescape mobile applications, https://github.com/CPHDH/Curatescape, (dostęp 24.11.2017).

${ }^{74}$ Proces instalacji oprogramowania przebiega identycznie jak w Omeka. Zob.: Installation - Omeka Classic User Manual, https://omeka.org/classic/docs/Installation/ Installation/, (dostęp 24.11.2017).

75 M.J. Souther, From Exhibition to Conversation., s. 5.

76 M.J. Souther, M. Owino, E.J. Bell, dz. cyt., s. 2.

77 M. Tebeau, Curatescape Workshop. 
podstawowe metadane $\mathrm{w}$ formacie Dublin Core, następnie wybrać specjalny typ elementu Curatescape oraz uzupełnić związane z nim informacje, później dołączyć pliki i opisać je metadanymi, dodać słowa kluczowe (tagi) oraz ustalić lokalizację dla elementu. Po opublikowaniu powstaje opowieść cyfrowa i zarazem zintegrowany obiekt archiwalny, który dostępny jest dla odbiorców od strony witryny (frontend).

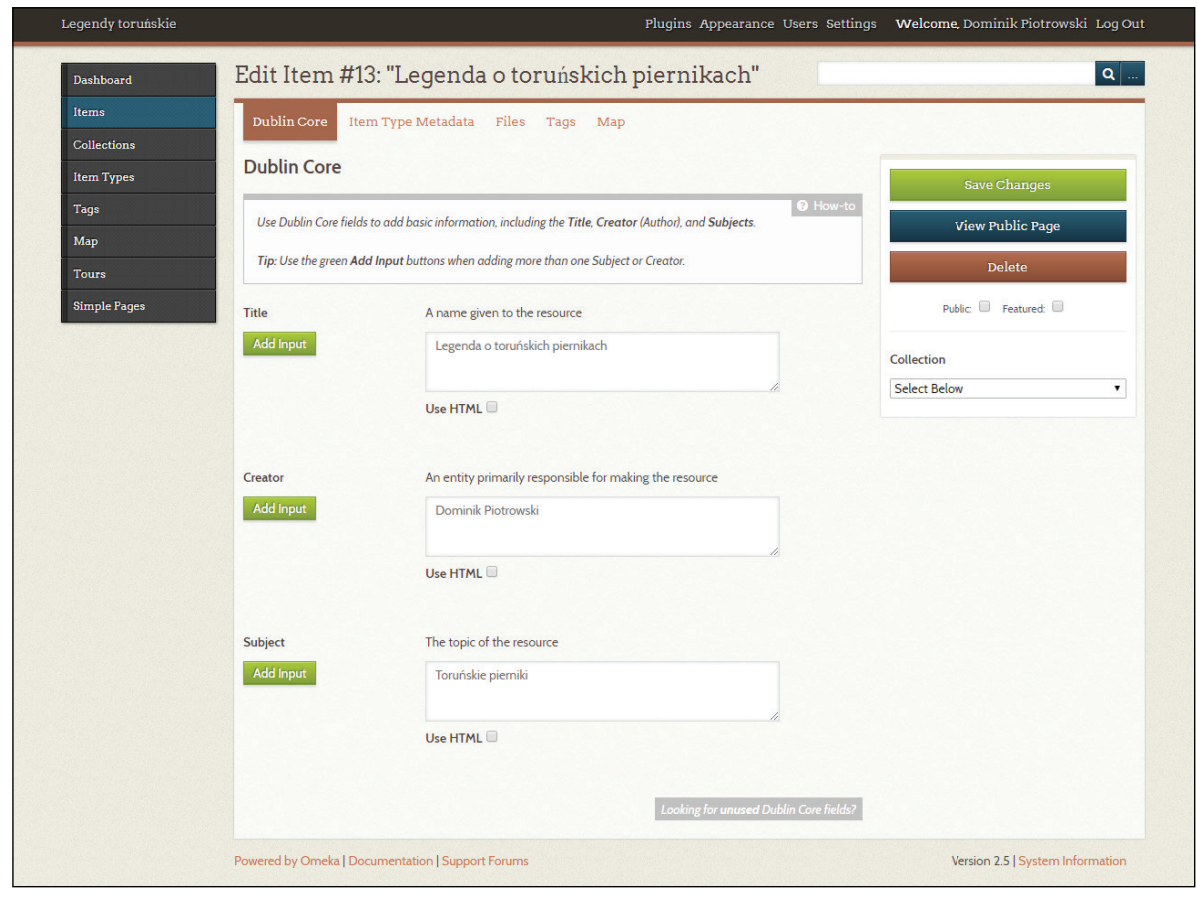

II. 7. Omeka + Curatescape backend - edycja elementu/opowieści

Źródło: Legendy toruńskie, https://domek.smarthost.pl/curatescape/admin/items /edit/13 (dostęp 24.11.2017)

Opowieści mogą być łączone w tzw. wycieczki (tours), które - jak wspomniano - stanowią kolejną warstwę interpretacyjną posiadającą np. charakter tematyczny lub geograficzny ${ }^{78}$. Wycieczki umożliwiają organizację opowieści oraz ich prezentację w wybranej kolejności w ramach grupy. Interesującą funk-

78 Tamże. 
cją oprogramowania jest tzw. „losowa opowieść”, która umożliwia podążanie użytkowników za losowo wyświetlonymi historiami i odkrywanie ciekawych opowieści.

Omeka do prezentacji zawartości wykorzystuje system motywów graficznych. W tym wypadku jest to responsywny motyw Curatescape. Dzięki temu rozwiązaniu zawartość wyświetlana jest w przeglądarce w formie aplikacji Internetowej, która dostosowuje układ do wielkości ekranu i jest poprawnie prezentowana zarówno na komputerach stacjonarnych, jak i urządzeniach mobilnych. Motyw posiada szerokie możliwości konfiguracyjne, dzięki którym w prosty sposób można dostosować witrynę do własnych potrzeb. W tym kontekście w szczególności wymienić należy opcje związane z mediami społecznościowymi i konfiguracją strony startowej, możliwość budowania świadomości marki poprzez zdefiniowanie kolorów oraz przesłanie pliku z logo, grafiki w tle oraz ikonki, a także zaawansowane ustawienia mapy i opcje związane z analityką. Użyteczne okazują się również niestandardowe etykiety dla opowieści i wycieczek, możliwość dodania funkcji komentowania, przesłania niestandardowego arkusza stylów CSS czy określenia statusu prawno-autorskiego witryny w oparciu o np. predefiniowane licencje Creative Commons.

\section{Jakie możliwości humanistyka cyfrowa oferuje instytucjom kultury, instytucjom edukacyjnym oraz lokalnym społecznościom?}

Z koncepcją 'kolektywnej organizacji miasta i historii'79 wiąże się konieczność trwałej współpracy humanistów cyfrowych z instytucjami LAM, lokalną społecznością, a także różnego typu organizacjami, przewodnikami i wolontariuszami. Marcin Wilkowski zauważa, że „wiele dziś mówi się o cyfryzacji, wciąż za mało uwagi poświęcając działaniom zmierzającym do lepszego wykorzystania zbiorów historycznych także poza kręgiem naukowym"80. Dlatego otwarty na dialog ze społecznością edukacyjny mobilny projekt interpretacyjny jest ważnym głosem w sprawie wychodzenia poza mury uniwersytetu do „zwykłych” ludzi. W dobie cyfrowej instytucje LAM podjęły współpracę ze społecznością w zakresie interpretacji historii lokalnej oraz łączenia wywiadów historii mówio-

79 Tenże, Update: Cleveland Historical.

${ }^{80}$ M. Wilkowski, Historia publiczna. 
nej z archiwalnymi materiałami, tworząc opowieści cyfrowe z zakresu historii w przestrzeni publicznej ${ }^{81}$.

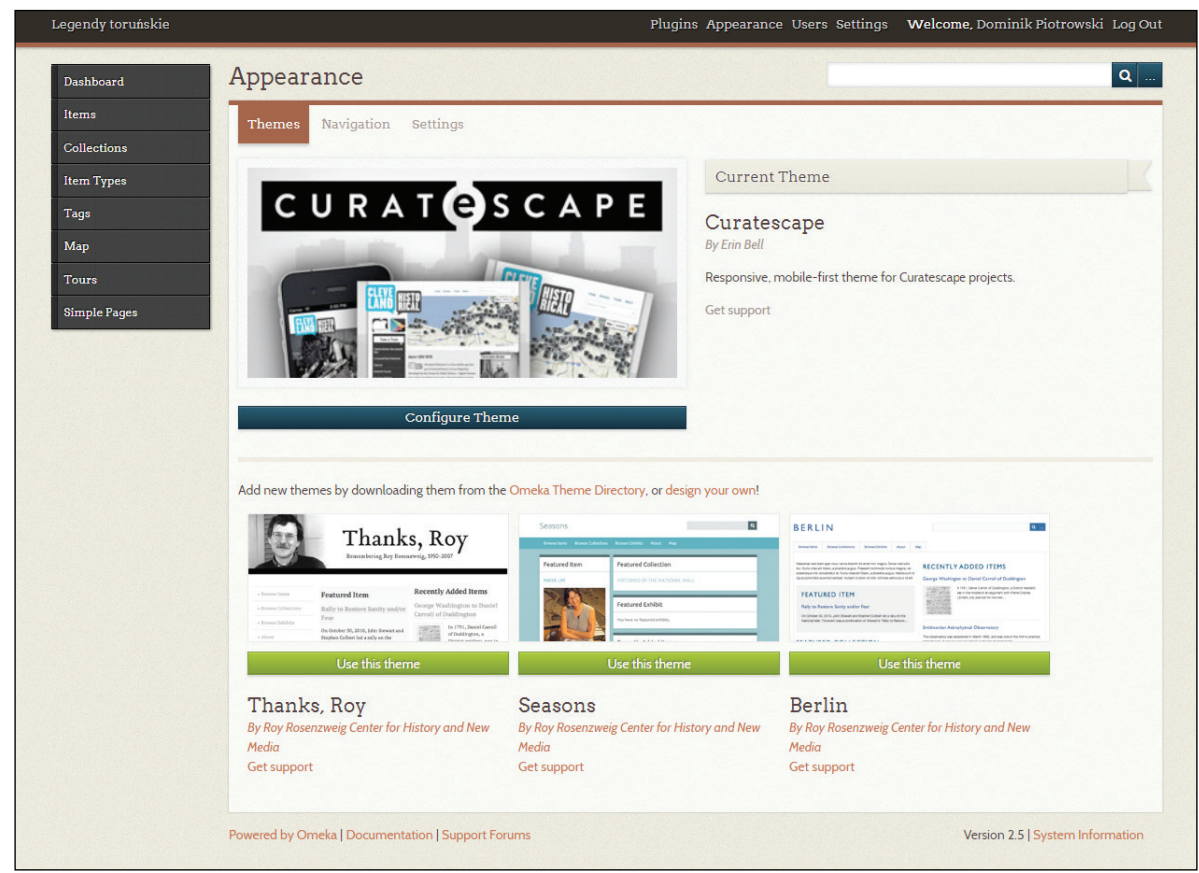

II. 8. Motyw graficzny Curatescape

Źródło: Legendy toruńskie, http://domek.smarthost.pl/curatescape/admin/ themes/browse (dostęp 24.11.2017)

Interesujący z punktu widzenia rozpatrywanej problematyki jest fakt, że w instytucjach LAM pracują specjaliści - kuratorzy ${ }^{82}$, którzy 'zawodowo zajmują się zgromadzoną w zbiorach treścią oraz interpretacją dziedzictwa kulturalnego's3; zarazem instytucje LAM gromadzą cyfrowe dziedzictwo ${ }^{84}$, toteż ważna staje się realizowana przez nie specjalistyczna opieka nad cennymi tre-

${ }^{81}$ Digital storytelling, wolna encyklopedia Wikipedia, https://en.wikipedia.org/wiki/ Digital_storytelling, (dostęp 24.11.2017).

82 Zob.: H. U. Obrist, Krótka historia kuratorstwa, Kraków 2016.

${ }^{83}$ Curator, Free Encyclopedia Wikipedia, https://en.wikipedia.org/wiki/Curator, (dostęp 24.11.2017).

84 Zob.: M. Wilkowski, Wprowadzenie do historii cyfrowej., s. 60. 
ściami oraz danymi w formie cyfrowej. W związku z powyższym, za autorami Przewodnika po kuratorstwie danych $w$ humanistyce cyfrowej, należy podkreślić, że obecnie biblioteki zobligowane są do pełnienia obowiązków związanych $\mathrm{z}$ kuratorstwem danych ${ }^{85}$, a w instytucjach tych powstało nowe stanowisko związane z kuratorstwem cyfrowym, mianowicie kurator danych cyfrowych ${ }^{86}$. W odniesieniu do tego, ważny wydaje się głos Arjuna Sabharwala, który zauważa, że „kuratorstwo cyfrowe i humanistyka cyfrowa [...] zawierają połączone ramy dla ochrony, promocji i dostępu do zbiorów cyfrowych" ${ }^{87}$ oraz współpracy „archiwistów, bibliotekarzy, humanistów cyfrowych, technologów, architektów informacji i społeczności" ${ }^{\prime 8}$. W kontekście niniejszych rozważań istotne staje się sprawowanie specjalistycznej opieki nad historią mówioną, gdyż coraz więcej bibliotek i archiwów podejmuje się gromadzenia tego typu treści cyfrowych, zapewniając dostęp do kolekcji wywiadów audio i video na potrzeby badań ${ }^{89}$. Jednocześnie biblioteki i archiwa posiadają w swoich zbiorach materiały, które obrazują wywiady świadków i uczestników historii ${ }^{90}$.

Nowoczesne technologie i humanistyka cyfrowa stwarzają pole do współpracy różnych grup interesariuszy, wykorzystujących metodologię i teorię historiografii cyfrowej podczas projektowania skutecznych historycznych reprezentacji cyfrowych ${ }^{91}$. Za Joshuą Sternfeldem należy podkreślić, że ramy dla historiografii cyfrowej stanowią trzy procesy archiwalne, mianowicie wybór, wyszukiwanie oraz zastosowanie metadanych, które „odblokowują wiele warstw kontekstualizacji historiografii cyfrowej" ${ }^{\prime 2}$. Historiografia cyfrowa opiera się również na takich dyscyplinach jak „bibliotekoznawstwo, studia muzealne i informatyka"93, a historyczne reprezentacje cyfrowe mogą być tworzone, przy współpracy naukowców oraz pracowników instytucji dziedzictwa, także za pomocą aplikacji Curatescape. Jednocześnie oprogramowanie Curatescape to rozwiązanie technologiczne przeznaczone „do nauczania oraz uczenia się"94.

${ }^{85}$ An Introduction to Humanities Data Curation - Digital Humanities Data Curation, https://guide.dhcuration.org/contents/intro/

${ }^{86}$ R. Patela, A. Piwko-Łętek, O. Sadlik, Kurator danych cyfrowych.

87 A. Sabharwal, Digital Curation in the Digital Humanities., s. 1.

88 Tamże, s. 11.

89 Oral History in the Digital Age, http://ohda.matrix.msu.edu/, (dostęp 24.11.2017).

90 M.J. Souther, From Exhibition to Conversation., s. 6-7.

91 J. Sternfeld, Archival Theory and Digital Historiography., s. 548-550.

92 Tamże, s. 548.

93 Tamże, s. 572.

${ }^{94}$ M.J. Souther, From Exhibition to Conversation, s. 5. 
W rezultacie współpraca różnych podmiotów oraz integracja wysokiej jakości treści cyfrowych umożliwia tworzenie nowoczesnych multimedialnych materiałów edukacyjnych z zakresu historii lokalnej. Jak zauważa Marta Smoleń-Sidyk „kluczem do sukcesu jest odpowiednia treść umiejętnie osadzona w kontekście"95, dlatego też skuteczną metodą są opowieści cyfrowe, które umożliwiają łatwiejsze przyswajanie oraz popularyzację treści historycznych. Dla przykładu, w omawianym obszarze, opowieści cyfrowe znalazły zastosowanie m.in. podczas lekcji w miejscowych szkołach ${ }^{96}$, z kolei instytucje kultury oraz lokalne organizacje zaczęły wykorzystywać, opartą na Curatescape, zawartość $\mathrm{CH}$ podczas realizacji różnego typu wycieczek ${ }^{97}$.

Jak wspomniano wcześniej, na bazie tytułowego oprogramowania powstało wiele ciekawych inicjatyw, które wykorzystują zasoby archiwów i bibliotek. Interesującym projektem, opartym na Curatescape, jest Ramble Bahamas ${ }^{98}$, który scharakteryzowany został w artykule pt. Ramble Bahamas: Pioneering Bahamian History and Culture in the Digital Age. Autorami publikacji, a zarazem kuratorami projektu, są Jessica R. Dawson oraz Tracey L. Thompson z „From Dat Time”: The Oral \& Public History Institute of the University of The Bahamas ${ }^{99}$. Idea wdrożenia oprogramowania Curatescape było stworzenie platformy na potrzeby realizowanych przez instytut badań naukowych, skupiających się na XX-wiecznej historii Bahamów, a także udostępnienie wyników szerszej publiczności, w tym m.in. uczniom, nauczycielom, studentom i wykładowcom ${ }^{100}$. Opowieści w Ramble Bahamas zgrupowane są w ramach „wędrówek” (ang. rambles) ${ }^{101}$. Pojedyncze opowieści, podobnie jak w innych projektach bazujących na Curatescape, oparte są na lokalizacji i zawierają narracyjny tekst dotyczący historii danego miejsca, zdigitalizowane dokumenty, ilustracje, zdjęcia, metadane oraz nagrania historii mówionej.

${ }_{95}$ M. Smoleń-Sidyk, „Digistoria” (interdyscyplinarny, interaktywny, polisensoryczny projekt edukacyjny), „Kultura i Historia” (25), 2014, http://www.kulturaihistoria.umcs. lublin.pl/archives/5268, (dostęp 24.11.2017).

96 M. Tebeau, Update: Cleveland Historical.

97 Tamże.

98 Ramble Bahamas, http://www.ramblebahamas.org/, (dostęp 24.11.2017).

99 J.R. Dawson, T.L. Thompson, Ramble Bahamas: Pioneering Bahamian History \& Culture in the Digital Age, „International Journal of Bahamian Studies”, 23 2017, s. 1-6, http://journals.sfu.ca/cob/index.php/files/article/view/285, (dostęp 24.11.2017).

100 Tamże, s. 2.

101 „Rambles” w języku bahamskim posiadają szersze znaczenie. Zob.: About | Ramble Bahamas, http://www.ramblebahamas.org/about, (dostęp 24.11.2017). 


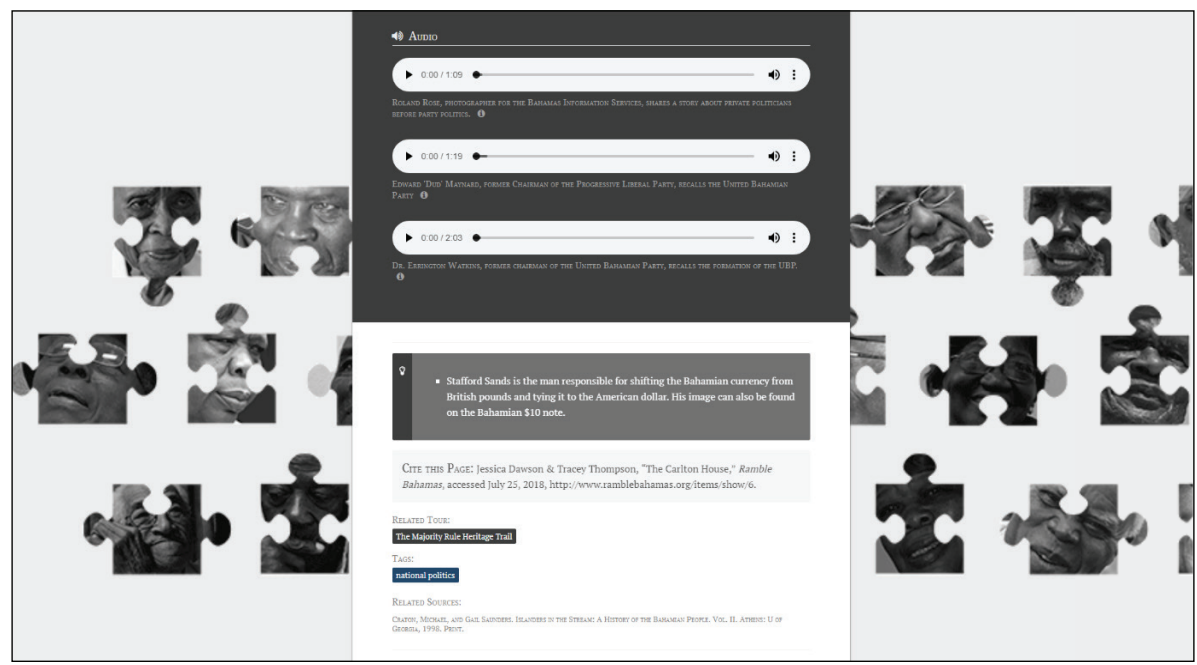

II. 9. The Carlton House w Ramble Bahamas

Źródło: J. Dawson, T. Thompson, The Carlton House, http://www.ramblebahamas.org/items/show/6 (dostęp 25.11.2018)

Innym ciekawym projektem z zakresu historii w przestrzeni publicznej, opartym na Curatescape, jest NW PA Heritage ${ }^{102}$. Projekt koncentruje się na historii północno-zachodniej części stanu Pensylwania w Stanach Zjednoczonych Ameryki. W tym przypadku, oprócz wersji przeznaczonej na przeglądarki internetowe, dostępne są także aplikacje natywne dla systemów iOS oraz Android. Zawartość witryny tworzona jest przez prywatną uczelnię Allegheny College „w partnerstwie z wieloma różnymi grupami dziedzictwa kulturowego"103 i obejmuje oparte na lokalizacji historyczne teksty interpretacyjne oraz zdjęcia. Projekt nieprzerwanie się rozwija, a jego twórcy są otwarci na lokalną współpracę w celu publikacji kolejnych historycznych opowieści ${ }^{104}$.

${ }^{102}$ NW PA Heritage, http://nwpaheritage.org/, (dostęp 24.11.2017).

103 A. Carr, NWPa Heritage Public History Project (Panel E), „Network Detroit: Digital Humanities Theory and Practice", 30.09.2016, https://digitalcommons.wayne.edu/ networkdetroit/2016/Sept30/29, (dostęp 24.11.2017).

104 About NWPa Heritage | NW PA Heritage, http://nwpaheritage.org/about/, (dostęp 24.11.2017). 


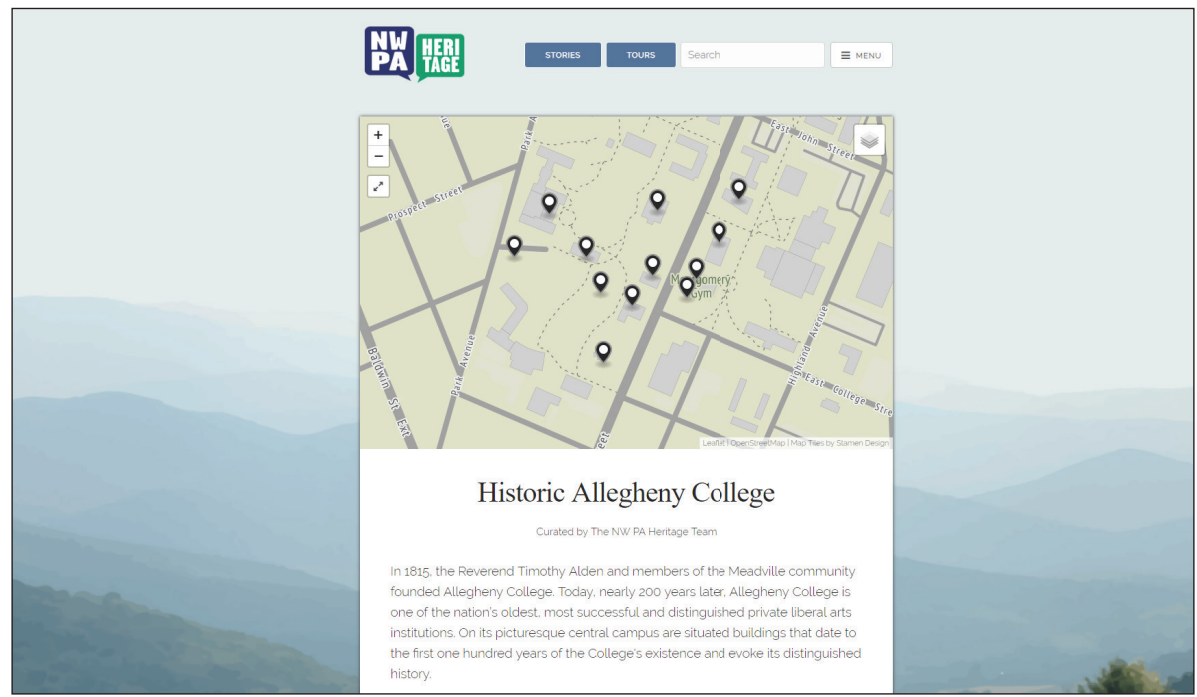

II. 10. Wprowadzenie do wycieczki Historic Allegheny College

Źródło: Allegheny College, http://nwpaheritage.org/tours/show/2 (dostęp 24.11-2017)

\section{Dyskusja}

Przeprowadzone analizy umożliwiły uzyskanie odpowiedzi na postawione pytania badawcze. W pierwszej kolejności scharakteryzowany został mobilny projekt interpretacyjny Cleveland Historical, który wraz z wcześniejszymi inicjatywami realizowanymi przez $\mathrm{CPHDH}$, przyczynił się do powstania aplikacji Curatescape. Następnie badaniom poddana została architektura informacji oraz funkcjonalności otwartego oprogramowania Omeka + Curatescape. Badania pozwoliły także wskazać na możliwości, jakie humanistyka cyfrowa oferuje instytucjom dziedzictwa kulturalnego, instytucjom edukacyjnym oraz lokalnym społecznościom. Na podstawie uzyskanych wyników można sformułować wnioski, będące odpowiedzią na następujące tezy:

1. Projekty oparte na Curatescape stwarzają pole do kolektywnej współpracy różnych grup interesariuszy oraz podkreślenia obecności archiwistów w społeczeństwie.

2. Mobilne projekty interpretacyjne mogą przyczynić się do rozwoju edukacji, budowania pamięci społecznej, wskazywania miejsc historycznych i rozwoju turystyki kulturowej. 
3. Oprogramowanie Omeka + Curatescape posiada przejrzystą i użyteczną architekturę informacji oraz praktyczne funkcjonalności, które pozwalają na tworzenie historycznych reprezentacji cyfrowych w nieskomplikowany sposób.

4. Inicjatywa stojąca za projektem $\mathrm{CH}$ znalazła wielu kontynuatorów w innych ośrodkach akademickich lub kulturalnych.

Badania pozwoliły ustalić, że dzięki Curatescape możliwa staje się wspólna realizacja projektów z zakresu humanistyki cyfrowej oraz współpraca naukowców, bibliotekarzy i archiwistów ze społecznością. Odwołując się, do zasygnalizowanej we wstępie, koncepcji przesunięcia paradygmatów archiwalnych wg Terry'ego Cooka, można stwierdzić, że opisywane oprogramowanie pozwala archiwistom na „dzielenie się archiwami ze społecznością” 105 oraz angażowanie społeczności w „interaktywne dialogi z głównymi archiwami i ich zasobami”"106. Zarazem takie nowoczesne narzędzia jak Curatescape umożliwiają współpracę naukowców oraz pracowników instytucji dziedzictwa na polu historiografii cyfrowej. Przy pomocy Curatescape humaniści cyfrowi i pracownicy instytucji LAM, członkowie lokalnych społeczności, „oddolni” historycy, nauczyciele oraz pasjonaci są w stanie współtworzyć zintegrowane obiekty archiwalne nowej generacji i zarazem unikatowe kolekcje online wpisujące się w publiczne dziedzictwo kulturalne. Wszystkie wymienione grupy interesariuszy mogą dodawać wartość i znaczenie cennym treściom i danym elektronicznym na potrzeby przyszłych badań, wpisując swoje działania w kuratorstwo cyfrowe.

Mobilne projekty interpretacyjne oparte na Curatescape mogą przyczynić się do ożywienia edukacji historycznej oraz budowania pamięci społecznej, która stanowi „zespół wyobrażeń o przeszłości grupy, a także wszystkie postacie i wydarzenia z tej przeszłości, które są w najróżniejszy sposób upamiętniane"107. W analizowanym przypadku pamięć społeczna, zwana także „zbiorową pamięcią historyczną"108, może być przekazywana za pomocą opowieści cyfrowych, które ułatwiają przyswajanie wiedzy. Z kolei dzięki geolokalizacji możliwe staje się precyzyjne wskazywanie miejsc historycznych, które są ważne z punktu widzenia historii w przestrzeni publicznej i historii miejskiej. Mobilne projekty

105 T. Cook, Evidence, Memory, Identity, and Community.

106 Tamże.

107 B. Szacka, Pamięć społeczna, [w:] Encyklopedia socjologii, t. 3, red. Z. Bokszański, H. Domański i in., Warszawa 2000, s. 52.

108 J. Klaś, Muzea historyczne - pomiędzy pamięcia zbiorową a polityka pamięci historycznej, „Zarządzanie w Kulturze”, 2013, 14, nr 3, http://www.ejournals.eu/sj/index. $\mathrm{php/ZwK/article/view/3671,} \mathrm{(dostęp} \mathrm{24.11.2017).}$ 
interpretacyjne mogą również sprzyjać rozwojowi turystyki historycznej, wpisującej się w turystykę kulturową, która „stała się trwałym i ważnym segmentem usług turystycznych" ${ }^{109}$. Inicjatywy oparte na Curatescape są w stanie wspierać różnego typu wycieczki i spacery miejskie, co z kolei może zwiększyć dostępność i widoczność zasobów instytucji kultury, a także wzbogacić wiedzę i świadomość społeczeństwa nt. dziedzictwa kulturalnego danego regionu.

Wyniki niniejszego badania pokazują, że oprogramowanie Omeka + Curatescape pozwala w prosty sposób gromadzić, zarządzać i udostępniać informacje odnoszące się do różnych miejsc, osób i wydarzeń. Omawiane rozwiązanie informatyczne umożliwia tworzenie uporządkowanych i dobrze zorganizowanych treści. Oprogramowanie posiada system nawigacyjny, który jest intuicyjny oraz zrozumiały i nie sprawia trudności podczas poruszania się zarówno po stronie zaplecza, jak również po stronie publicznie dostępnej witryny. Nawigacja pozwala użytkownikom na dokonywanie różnych odkryć, chociażby za pomocą wspomnianej funkcji „losowa opowieść”. Domyślny system etykietowania jest czytelny. System wyszukiwawczy umożliwia przeszukiwanie całej witryny, zaawansowane wyszukiwanie opowieści, a także przeglądanie słów kluczowych oraz wszystkich opowieści. Oprogramowanie posiada wiele praktycznych funkcjonalności (w tym wbudowanych funkcji resposnywanego szablonu graficznego), które rozszerzają możliwości platformy. Z kolei sposobność osadzania treści multimedialnych sprawia, że zawartość jest atrakcyjna dla odbiorców, co może przełożyć się na zwiększenie zaangażowania i interakcji.

Inicjatywa stojąca za projektem $\mathrm{CH}$ znalazła wielu kontynuatorów w innych (głównie zlokalizowanych w USA) ośrodkach akademickich lub kulturalnych. Zasadniczy wpływ na taki stan rzeczy ma rosnące zainteresowanie historią w przestrzeni publicznej, a także zaprojektowanie, a następnie udostępnienie przez $\mathrm{CPHDH}$ otwartego oprogramowania Curatescape. Co ciekawe, obecnie tworzone są alternatywne otwartoźródłowe narzędzia sieciowe do realizacji projektów z zakresu budowy dziedzictwa publicznego ${ }^{110}$. W pierwszej kolejności wymienić należy, „odchudzoną” i posiadającą uproszczone przepływy pracy, wtyczkę Curatescape dla popularnego otwartoźródłowego systemu WordPress ${ }^{111}$,

109 A.M. von Rohrscheidt, Turystyka kulturowa: fenomen, potencjat, perspektywy, Poznań 2010, s. 9.

110 Zob.: E. Watrall, Public heritage at scale. Building tools for authoring mobile digital heritage and archaeology experiences, „Journal of Community Archaeology \& Heritage”, 2017, s. 1-14.

111 GitHub-CPHDH/wp_curatescape: Curatescape for WordPress, https://github.com/ CPHDH/wp_curatescape, (dostęp 24.11.2017). 
która stworzona została na potrzeby projektu Curating Kisumu. Kolejnym interesującym rozwiązaniem jest mbira (aktualnie w wersji beta), czyli aplikacja zaprojektowana przez Matrix: Center for Digital Humanities and Social Sciences at Michigan State University. Mbira przeznaczona jest „do tworzenia i zarządzania opartymi na lokalizacji i mobilnymi doświadczeniami dziedzictwa kulturowego"112. Innym tego typu rozwiązaniem może być (aktualnie w wersji alpha) TourSites for WordPress ${ }^{113}$, czyli projekt stworzony w ramach współpracy Ohio History Connection oraz $\mathrm{CPHDH}^{114}$.

Ciekawymi zagadnieniami, które mogą stanowić propozycję dalszych prac badawczych związanych z poruszaną w niniejszym artykule problematyką są:

1. Kuratorstwo cyfrowe zbiorów archiwalnych i muzealnych oraz bibliotecznych kolekcji specjalnych w środowisku sieciowym za pomocą aplikacji do zarządzania treścią typu open source.

2. Zastosowanie metadanych (np. związanych z lokalizacją lub datą) $\mathrm{w}$ tworzeniu historiografii cyfrowej, albowiem metadane pozwalają badaczom tworzyć nowe relacje i wiedzę ${ }^{115}$.

3. Optymalizacja mediów społecznościowych oraz marketing w mediach społecznościowych w celu nawiązywania relacji z publicznością podczas realizacji projektów z zakresu historii w przestrzeni publicznej.

\section{Konkluzja}

Świat nauki oferuje niezwykle przydatne rozwiązania w funkcjonowaniu nowoczesnych instytucji LAM w postaci możliwości sprawowania opieki nad miastem (regionem), wsparcia edukacji historycznej, budowania pamięci społecznej, aktywizacji publiczności, rozwoju turystyki kulturowej oraz realizacji kuratorstwa cyfrowego. Zdaniem autora artykułu, Curatescape może stać się znaczącym projektem z zakresu humanistyki cyfrowej, który angażuje badaczy, archiwistów, bibliotekarzy, muzealników i publiczność oraz wyznacza nowe kierunki w nauczaniu i badaniach. Autor wyraża również nadzieję, że dzięki

112 mbira | mobile heritage platform, http://mbira.matrix.msu.edu/, (dostęp 24.11.2017).

113 GitHub-CPHDH/history_tours: A WordPress plugin for creating mappable historical tours, https://github.com/CPHDH/history_tours, (dostęp 28.11.2017).

114 About \& TourSites for WordPress, http://toursites.org/about/, (dostęp 28.11.2017).

115 A. Sabharwal, Digital Curation in the Digital Humanities., s. 55-67. 
niniejszym badaniom, także polscy humaniści cyfrowi, pracownicy instytucji dziedzictwa, nauczyciele oraz pasjonaci zainteresują się otwartym oprogramowaniem Curatescape. Należy jednak pamiętać, że mobilny projekt interpretacyjny współtworzony z różnymi podmiotami wymaga ciągłej współpracy oraz stałej opieki i rozwoju ${ }^{116}$.

\section{Bibliografia}

Bonecki, Mateusz. „Jerzy Kmita - interpretacja humanistyczna i społeczno-regulacyjna koncepcja kultury." Filozofia Publiczna i Edukacja Demokratyczna 1, nr 2 (2012): 178-198. http://cejsh.icm.edu.pl/cejsh/element/bwmeta1.element.desklight-af7ce386-852a-48e3-8851-d322af60ee7f/c/13a-Bonecki_1_.pdf.

Brown, Caroline. „Memory, Identity and the Archival Paradigm: Introduction to the Special Issue." Archival Science 13, nr 2-3 (2013): 85-93. https://doi.org/10.1007/ s10502-013-9203-z.

Carr, Amelia. „NWPa Heritage Public History Project (Panel E).” Dostęp 24.11.2017. https://digitalcommons.wayne.edu/networkdetroit/2016/Sept30/29.

Center for Public History + Digital Humanities at Cleveland State University. „Cleveland Cultural Gardens.” Dostęp 24.11.2017. https://csudigitalhumanities.org/2008/01/ cleveland-cultural-gardens/.

Center for Public History + Digital Humanities at Cleveland State University. „Cleveland Voices." Dostęp. 24.11.2017. https://clevelandvoices.org/.

Center for Public History + Digital Humanities at Cleveland State University. „Euclid Corridor Oral History Project.” Dostęp: 24.11.2017. https://csudigitalhumanities. org/2008/05/euclid-corridor-oral-history-project-2/.

Cleveland Cultural Gardens. Dostęp 24.11.2017. http://www.culturalgardens.org/.

Cleveland Cultural Gardens. „Polish Garden.” Dostęp 24.11.2017. http://www.culturalgardens.org/garden/polish-garden/

Cohen. Daniel J., Federica Frabetti, Dino Buzzetti, Jesus. D. Rodriguez-Velasco. „Defining the Digital Humanities." Columbia University Academic Commons (2011). https:// doi.org/10.7916/D8MS41Z1

Curatescape. Dostęp 24.11.2017. https://curatescape.org/.

Curatescape. „Pricing.” Dostęp 24.11.2017. https://curatescape.org/about/pricing/.

Curatescape. „Projects.” Dostęp 24.11.2017. https://curatescape.org/about/projects/.

Curatescape Forum. Dostęp 24.11.2017.http://forum.curatescape.org/.

Dawson, Jessica R., Tracey L. Thompson. „Ramble Bahamas: Pioneering Bahamian History \& Culture in the Digital Age." International Journal of Bahamian Studies 23 (2017). http://dx.doi.org/10.15362/ijbs.v23i0.285.

116 M. Tebeau, White Paper: Strategies for Mobile. 
Digital Curation Centre. „What is digital curation?” Dostęp 24.11.2017. http://www. dcc.ac.uk/digital-curation/what-digital-curation.

Digital Humanities Data Curation. „An Introduction to Humanities Data Curation.” Dostęp 25.11.2017. https://guide.dhcuration.org/contents/intro/.

Digital Humanities Data Curation. „Welcome.” Dostęp 24.11.2017. http://guide.dhcuration.org/.

Educational Uses of Digital Storytelling. „What is Digital Storytelling?” Dostęp 24.11. 2017. http://digitalstorytelling.coe.uh.edu/page.cfm?id $=27 \&$ cid $=27$.

GitHub. „About Curatescape.” Dostęp 24.11.2017. https://github.com/CPHDH/Curatescape.

GitHub. „CPHDH / CuratescapeWiki.” Dostęp 24.11.2017. https://github.com/CPHDH/ Curatescape/wiki.

GitHub. „Omeka Classic User Manual.” Dostęp 24.11.2017. https://omeka.org/classic/ docs/Installation/Installation/.

Illg, Jacek, Tomasz Illg. Słownik informatyczny: angielsko-polski, polsko-angielski. Katowice: „Videograf II”, 2003.

Januszko-Szakiel, Aneta. „Trwała ochrona zasobów cyfrowych - podstawowe pojęcia.” Biuletyn EBIB 154 (2015). http://open.ebib.pl/ojs/index.php/ebib/article/ view/311/481.

Kierzkowski, Michał. „Historia mówiona - próba definicji pojęcia.” Wrocławski Rocznik Historii Mówionej 4 (2017) 5-20. https://doi.org/10.26774/wrhm.64.

Klaś, Jarosław. „Muzea historyczne - pomiędzy pamięcią zbiorową a polityką pamięci historycznej." Zarządzanie w Kulturze 14, nr 3 (2013): 197-215. https://doi.org/1 0.4467/20843976ZK.13.013.133.

MacKay, Nancy. Curating oral histories: what to do after the interview. Walnut Creek, Calif.: Left Coast Press, 2007.

MaCleKi. Dostęp 24.11.2017. http://macleki.org/.

„Mobile Historical.” Dostęp: 24.11.2017. https://securegrants.neh.gov/publicquery/ main.aspx $\mathrm{f}=1 \& \mathrm{gn}=\mathrm{HD}-51456-11$

NWPa Heritage. „About.” Dostęp 24.11.2017. http://nwpaheritage.org/about/.

NWPa Heritage. Dostęp 24.11.2017. http://nwpaheritage.org.

Obrist, Hans Ulrich. Krótka historia kuratorstwa. Przekł. Martyna Nowicka. Kraków: Korporacja Ha!art, 2016.

OHA Oral History Association. „Oral History: Defined.” Dostęp 24.11.2017. http://www. oralhistory.org/about/do-oral-history/.

Omeka. DOstęp 24.11.2017. http://omeka.org.

Oral History in the Digital Age. Dostęp 24.11.2017. http://ohda.matrix.msu.edu/.

Patela, Renata, Anna Piwko-Łętek, Oliwier Sadlik. „Kurator danych cyfrowych - nowe stanowisko w bibliotece naukowej." Biuletyn EBIB 154 (2015). http://open.ebib.pl/ ojs/index.php/ebib/article/view/307.

RAMBLE Bahamas. Dostęp: 24.11.2017. http://www.ramblebahamas.org/.

RAMBLE Bahamas. „About.” Dostęp 24.11.2017. http://www.ramblebahamas.org/about. 
Robin, Bernard R. „Digital Storytelling: A Powerful Technology Tool for the 21st Century Classroom.”, Theory Into Practice 47 (2008): 220-228. https://doi.org/10. 1080/00405840802153916.

Rohrscheidt von, Armin Miklos. Turystyka kulturowa: fenomen, potencjat, perspektywy. Poznań: Wydawnictwo KulTour, 2010.

Sabharwal, Arjun. Digital Curation in the Digital Humanities: Preserving and Promoting Archival and Special Collections, Amsterdam [i in]: Elsevier/Chandos Publishing, 2015.

Smoleń-Sidyk Marta. „Digistoria (interdyscyplinarny, interaktywny, polisensoryczny projekt edukacyjny).” Kultura i Historia 25 (2014). http://www.kulturaihistoria. umcs.lublin.pl/archives/5268.

Souther, J. Mark. „From Exhibition to Conversation: The Elusive Art of Digital Storytelling." Opublikowane 30.09.2016. http://digitalcommons.wayne.edu/cgi/viewcontent. cgi ?article $=1001 \&$ context $=$ networkdetroit.

Souther, J. Mark, Meshack Owino, Erin J. Bell. „Adapting Mobile Humanities Interpretation in East Africa." Opublikowano 15.03.2016. http://csudigitalhumanities.org/ wp-content/uploads/2016/03/HD-51912-14_White-Paper.pdf.

Sternfeld, Joshua. „Archival Theory and Digital Historiography: Selection, Search, and Metadata as Archival Processes for Assessing Historical Contextualization.” The American Archivist 74, nr 2 (2011): 544-575. https://doi.org/10.17723/ aarc.74.2.644851p6gmg432h0.

Stevens, J. Richard. „Digital Curation's Dilemma. Contrasting Different Uses, Purposes, Goals, Strategies, and Values." International Journal of Technology, Knowledge \& Society 9, nr 4 (2013): 1-11. https://doi.org/10.18848/1832-3669/CGP/v09i04/56399.

Szacka, Barbara. „Pamięć społeczna”. W Encyklopedia socjologii, t. 3, red. Zbigniew Bokszański, Henryk Domański et al., 52-55. Warszawa: Oficyna Naukowa, 2000.

Tebeau, Mark. „Case Study: Visualizing Oral History,” W Oral History in the Digital Age, red. Doug Boyd, Steve Cohen, Brad Rakerd, and Dean Rehberger. Washington, D.C.: Institute of Museum and Library Services, 2012. http://ohda.matrix.msu. edu/2012/06/visualizing-oral-history/.

Tebeau, Mark. „Curatescape Workshop - YouTube - Brown University.” Dostęp 24.11.2017. https://www.youtube.com/watch?v=SgX_3_iT3yQ.

Tebeau, Mark. „Listening to the City: Oral History and Place in the Digital Era.” The Oral History Review 40, nr 1 (2013): 25-35. https://doi.org/10.1093/ohr/oht037.

Tebeau, Mark. „Strategies for Mobile Interpretive projects for Humanists and Cultural Organizations." Opublikowano 03.2013. http://mobilehistorical.curatescape.org/.

Tebeau Mark. „Update: Cleveland Historical to Curatescape.” Dostęp 24.11.2017 http:// csudigitalhumanities.org/2011/07/update-cleveland-historical/.

Töwe, Mathias. „Ochrona zasobów cyfrowych w Politechnice Federalnej w Zurychu. Potrzeby naukowców i wizja Biblioteki Uniwersyteckiej ETH w Zurychu.” W Wokót zagadnień trwałej ochrony zasobów cyfrowych, red. Aneta Januszko-Szakiel, 27-43. Kraków: Oficyna Wydawnicza AFM, 2013.

Watrall, Ethan. „Public heritage at scale: Building tools for authoring mobile digital heritage and archaeology experiences." Journal of Community Archaeology \& Heritage 5, nr 2 (2017): 114-127. https://doi.org/10.1080/20518196.2017.1334619. 
Wikibooks. „Materiały do nauk administracyjnych/Interpretacja humanistyczna.” Dostęp 24.11.2017. https://pl.wikibooks.org/wiki/Materia\%C5\%82y_do_nauk_administracyjnych/Interpretacja_humanistyczna.

Wikipedia. „Curator.” Dostęp 24.11.2017. https://en.wikipedia.org/wiki/Curator.

Wikipedia. „Digital storytelling.” Dostęp 24.11.2017. https://en.wikipedia.org/wiki/ Digital_storytelling.

Wilkowski, Marcin. „Digital storytelling: nowa jakość opowiadania.” Opublikowano 12.11.209.http://historiaimedia.org/2009/11/12/digital-storytelling-nowa-jakosc -opowiadania/index.html.

Wilkowski, Marcin. „Historia publiczna”, Tygodnik Powszechny, 18.11.2013. https://www. tygodnikpowszechny.pl/historia-publiczna-21168.

Wilkowski, Marcin. Wprowadzenie do historii cyfrowej. Gdańsk: Instytut Kultury Miejskiej, 2013. http://dane.historiaimedia.org/hc/wprowadzenie_do_historii_cyfrowej.pdf.

Wojdon, Joanna. „Public history, czyli historia w przestrzeni publicznej.” Klio - Czasopismo Poświęcone Dziejom Polski i Powszechnym 34, nr 4 (2015): 25-41. http://dx.doi. org/10.12775/KLIO.2015.027.

Żeglińska, Anna. „Relacje oral history jako obiekty archiwalne.” Archiwa - Kancelarie Zbiory 2(4) (2011): 145-154. 
